\title{
Linguistic Transparency and Opacity in Compounding
}

\author{
Doc. Dr. Esmeralda Sherko
}

Agricultural University of Tirana, Albania; aldasotiri@yahoo.com

\section{Doi:10.5901/ajis.2015.v4n3s1p590}

\section{Abstract}

The aim of this study is to identify linguistic transparency and opacity in compounds. Linguistic transparency and opacity analyses the degree to which the meaning of a compound word or idiom can be inferred from its parts. Compounding is a word formation process in which a lexical unit is made up of more than one word functioning as one, not only grammatically, but also semantically. Compounds and the meaning inferred by them may be: full, partial or idiomatic. Detailed analysis of the word classifies linguistic transparency or opacity as follows: two transparent constituents, transparent - opaque constituent, opaquetransparent constituent, two opaque constituents. As of the compositionality principle, constituents of compounds will be analysed separately and as a whole. Analysis will be illustrated with abundant examples of compound words collected by the Dictionary of Contemporary Albanian language and Oxford Student's Dictionary. Translation of several words from English into Albanian and vice versa will be provided so as to pinpoint the matches and mismatches.

Keywords: linguistics, transparency, opacity, compounding, translation

\section{Introduction to Linguistic Transparency}

Linguistic transparency is a broad concept used in different subjects. As of linguistics it refers to Semantic Transparency (ST). ST analyses the degree to which the meaning of a compound word or idiom can be inferred from its parts. Compounds are lexical units made up of more than one word functioning as one, not only grammatically, but also semantically. Compounding as a productive morphological word formation process is often subject to semantic drift, thus leading to opacity. This theory classifies compounds as semantically transparent and semantically opaque. Morphosemantic analysis of compounds examines constituents of compounds as binary structures, so analysis always considers two words although the compound may have more than two constituents. For example:

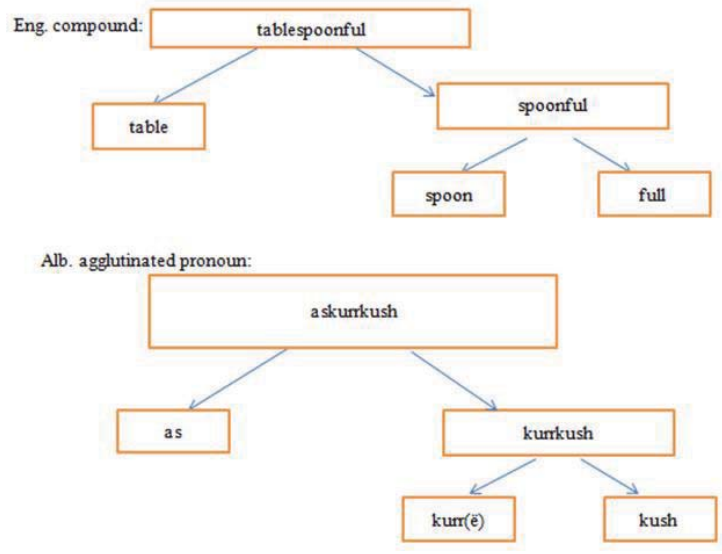

\section{Semantic Transparency in English}

Compound words represent lexical units connected by syntactic rules, which can be parsed into two or more meaningful elements or morphemes. English compounds are classified as endocentric and exocentric. Liebben (2003) classifies four fundamental degrees of morphosemantic transparency of compounds: 
a) transparency of both constituents - (TT)

b) transparency of the head member - opacity of the non-head member (TO),

c) transparency of the non-head member - opacity of the head member (OT),

d) opacity of both members of the compound (OO).

Schematic representation of each type:
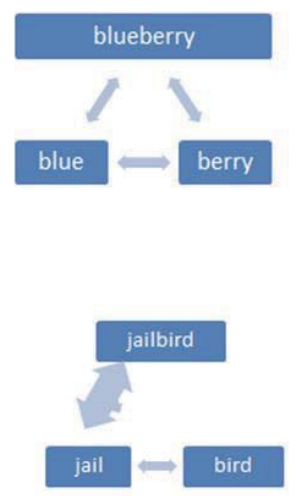

\section{eyewitness}

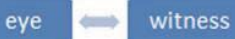

Libben ${ }^{1}$ has conducted a detailed survey on the relation between semantic transparency and compounds considering compounds based on the stimulus, lexical and conceptual levels. The study highlighted that words belonging to different categories of transparency yielded similarities as of the stimulus and lexical levels. Thus it is the conceptual level which plays a significant role. The conceptual level refers to the principle of compositionality as well as to the individual meaning of the separate constituents. As of the compositionality principle, semantic transparency takes into consideration two forms: predictability and analyzability.

Predictability as of Plag $(2003,46)$ defines as semantically transparent words, compounds whose "meaning is predictable on the basis of the word-formation rule according to which they have been formed."

Whereas analyzability as of Zwitserlood $(1994,344)$ infers that "the meaning of a fully transparent compound is synchronically related to the meaning of its composite words".

Based on these principles we consider the compound "storybook" which means "a book containing stories"; if we go on with the same principle we would assume that the compound "cookbook" means "a book containing cooks", but a "cookbook " is "a book containing recipes for cooking". In case of full opacity, analyzability and predictability by parsing of the constituents would lead to a wrong interpretation.

E.g.: a Redcoat is a British soldier and not "a coat that is red".

There are also cases when interpretation of 00 compounds based on cultural grounds would lead to the right understanding. Let us consider for example the English compound "black sheep", where "black" refers to the colour, and "sheep" refers to the animal. The Albanian translation "delja e zezë" does not appear in the Dictionary of Albanian language, but everyone understands and uses it with the exact same meaning as in English.

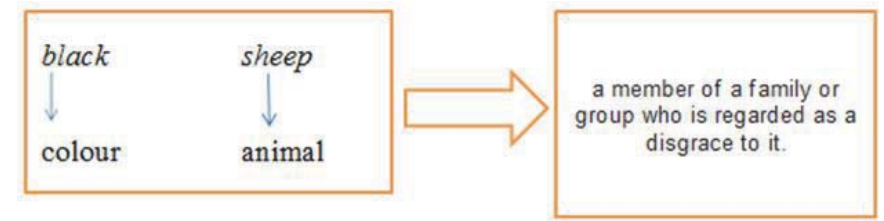

http://www.sciencedirect.com/science/article/pii/S0093934X97918769

* - "cook" - note the difference in meaning between the verb and the noun in the case of "cook" (this compound yields the same meaning even in other languages) 


\section{Semantic Transparency in Albanian}

The meaning of compound words in Albanian is inferred by parsing the word in its constituent parts. Generally the meaning of compound words is perceived as the sum of the meanings of its constituents. Thus Albanian language classifies compounds into two categories: coordinate and subordinate. This classification derives from the relation between the elements constituting the compound. Coordinate compounds almost always yield the meaning from the sum of meanings from the constituents, e.g. ekonomiko-shoqëror = ekonomik and shoqëror, whereas subordinate compounds yield a new notion, although the meaning of the new compound derives from the relation between the constituents, e.g. keqkuptoj = kuptoj keq.

Examples of coordinate and subordinate compounds:

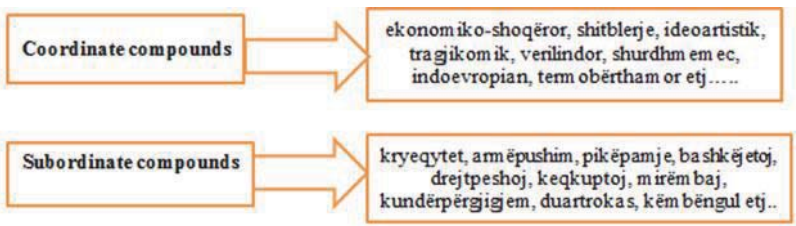

However Albanian language categorizes and studies agglutinated words separately, not as compounds. Agglutinated words are also said to have e clearly identifiable meaning,

e.g.

$$
\text { kuqezi } \longrightarrow \text { kuq ezi }
$$

but not all of them. Motivation plays a considerable role when it comes to the semantics of agglutinated words. For example:

Alb:

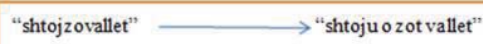

\section{Types of Semantic Transparency}

Dressler distinguishes four fundamental degrees of morphosemantic transparency of compounds:

1. transparency of both members of the compound: this category includes words whose meaning can be predicted by parsing the word in its constituents and analyzing their meaning separately.

\begin{tabular}{|l|l|}
\hline English & $\begin{array}{l}\text { hand+bag, police+man, blue+berry, door+bell, storybook, blueberry, } \\
\text { bedroom, carwash, lunchtime, newspaper }\end{array}$ \\
\hline Albanian & letër+këmbim, pikë+mbërritje, qendër+sulmues, ulli+rritës, as+një \\
\hline
\end{tabular}

2. transparency of the head member, opacity of the non-head member:

\begin{tabular}{|l|l|}
\hline English & straw +berry, red+faced, eye+witness, ill+treat \\
\hline Albanian & krye+qytet, as+kush, as+\{kurr(ë)+kush $\}$ \\
\hline
\end{tabular}

3. transparency of the non-head member, opacity of the head member:

\begin{tabular}{|l|c|}
\hline English & jail+bird, green+house \\
\hline Albanian & thanë+keqe, , udhë+heqës \\
\hline
\end{tabular}

4. opacity of both members of the compound:

\begin{tabular}{|l|l|}
\hline English & hum+bug, dead+line, pine+apple \\
\hline Albanian & tretë+natë, shtojzo+rreshta, \\
\hline
\end{tabular}




\section{Conclusions}

In theory the concept of semantic transparency in both languages represents similarities and differences. Translation of compounds from one language into the other provides various results:

1. the compound word in both languages is the result of exactly the same constituents, as in:

at + dhe $=$ father + land

a eroplanm bajtëse $=$ aircraftcarrier

2. compound word in Albanian $\rightarrow$ derivative word in English:

faqebardhë $=$ successful $/$ honoured

3. compound word in Albanian simple word in English

faqelarë $=$ clean $/$ honest

\section{References}

Akademia e shkencave, Fjalor i gjuhës së sotme shqipe, Tiranë, 1980

Akademia e shkencave, Gramatika e gjuhës shqipe I, Tiranë, 1995

Akademia e shkencave, Gramatika e gjuhës shqipe I, Tiranë, 2002

Bauer Laurie, When is a sequence of noun + noun a compound in English?, English Language and Linguistics 2

Downing, P. (1977). On the creation and use of English compound nouns.

Frederick W. Field, Linguistic Borrowing in Bilingual Contexts. John Benjamins, 2002

Libben G. (1998). Semantic transparency in the processing of compounds: consequences for representation, processing, and impairment.

Pavol Štekauer, Meaning Predictability in Word Formation. John Benjamins, 2005

Plag, I. (2003). Word-Formation in English. Cambridge: Cambridge University Press.

Qesku Pavli, Fjalor Shqip- Anglisht, Tiranë 2002 